\title{
Job analysis of Ex-Officio Head of Batam Indonesia Free Zone Authority (BP Batam): Relationship between Performance and Political Relation
}

\author{
Ady Muzwardi \\ Department of International Relations, Universitas Maritim Raja Ali Haji
}

Correspondence : ady muzwardi@umrah.ac.id

\section{ARTICLE INFO}

Article History

Submited; May 19, 2021

Revised; June 14, 2021

Accepted; June 29, 2021

Available online: July 07,2021

Keyword

Ex-Officio

Head of BP Batam

Performance

Political Relations

\begin{abstract}
On 27 September 2019 the Mayor of Batam officially became the ex officio Head of Batam Indonesia Free Zone Authority (BP Batam). The ex-officio term of the Head of BP Batam is the same as the term of office of the mayor of Batam. The ex-officio position of the Head of BP. Batam is a new position in Indonesia. This position combines a political position, namely the mayor of Batam with a professional position in the Concession Board. ex-officio Head of BP Batam was formed as a means to reduce the conflict of leadership dualism in Batam City. The ex-officio position of the Head of BP Batam spans with political relations that are full of interests so that potential obstacles in developing performance can occur. This study aims to analyze the ex-officio performance of the Head of BP Batam and analyze the political relations in the ex-officio position of the Head of BP Batam and see its performance in the first year during the covid 19 pandemic. This study uses a qualitative method. Data collection techniques in this study used documentation studies and field studies. The results of this study explain that the ex.officio leadership function of the Head of BP Batam in the early years has gone according to plan, although there are some.
\end{abstract}

\section{INTRODUCTION}

On 27 September 2019 the Mayor of Batam officially became the ex-officio of the Head of the Batam Concession Agency. The ex-officio term of the Head of BP Batam is the same as the term of office of the mayor of Batam. The ex-officio position of the Head of BP Batam is only valid for the second period of the mayor of Batam (Muhammad Rudi), namely 2019 to 2024 (Rezkisari, 2021). The ex-officio position of Head of BP Batam is a new position in Indonesia. This position combines a political position, namely the mayor of Batam with a professional position in the Business Board, namely the head of BP Batam. based on legal terminology, the ex-officio of the Head of BP Batam is not a state official so this position can be ex-officio with the Mayor of Batam (interview with the Legal Bureau of the Coordinating Ministry for the Economy, 2019). Institutionally, BP Batam is a business entity tasked with developing the industrial area of Batam Island. BP Batam itself is a carry over from the Batam Authority, a single agency for the development of the island of Batam which was formed before the Batam City Government. The change of the Batam Authority to become the Batam 
Concession Board cannot be separated from the formation of the Free Trade Area and Free Port (KPBPB). In PP 46 it is stated that the Batam Island Industrial Area Development Authority has changed to the Batam Area Concession Agency or BP-Batam for short and that BP Batam has existed for 70 years since PP 46 was signed. In addition, in PP No. 2 of 2009 it was reaffirmed that BP. Batam was formed by the Regional Council and the duties of the Free Trade Area and Free Port Concession Agency have the duty and authority to carry out management, development and development (3P) in free trade areas and free ports Batam. (Muzwardi, 2017).

In contrast to BP Batam, Batam City Government in its tupoksi is based on the Law of the Republic of Indonesia Number 32 of 2004 concerning Regional Government that regional autonomy is the right, authority and obligation of autonomous regions to regulate and manage their own government affairs and the interests of the local community in accordance with statutory regulations. invitation. The existence of these two institutions gave birth to overlapping authorities. The powers that become conflicts between the two institutions are: 1) Public works; 2) Spatial planning; 3) Development planning; 4) Housing; 5) Transportation; 6) Investment; 7) Communication and informatics 8) Forestry Land; 9) Infrastructure Tourism (water, electricity, roads).

The conflict between BP Batam and Pemko Batam began to exist when the presence of an autonomous region, namely Batam City, created an overlapping authority between Pemko Batam and the Concession Board. The existence of these two institutions which are supported by different legal substances and structures makes the implementation of Batam's management policies not harmonious (Zaenuddin et al., 2017). The central government as the mediator of the conflict issued Law no. 53 of 1999 concerning the City of Batam. The law is expected to harmonize the relationship between BP Batam and Pemko Batam. According to Article 21 of the Law, there are two statements regarding the relationship between the two institutions, namely "The working relationship between the Batam City Government and the Batam Authority Agency is further regulated by Government Regulation" and "With the formation of Batam City as an Autonomous Region, the Batam City Government in the administration of government and development in the area to include the Batam Authority Agency". The statement on the existence of a Government Regulation related to the harmonization of relations between BP Batam and Pemko Batam in article 21 has never been implemented (Alfiandri \& Mahadiansar, 2020)

In the absence of the PP promised in Law no. 53 of 1999 caused a conflict of authority between BP Batam and Pemko Batam which gave birth to sectoral egos in the two institutions (Effendi et al., 2019). Basically, dualism occurs because of the reluctance of BP Batam to stop their presence in the management of the Batam area more because of their strength based on the impulse of ego because they feel they have developed Batam from its initial condition (Dalla et al., 2018) One of the main conflicts between the two institutions is the dualism of land authority due to the management rights that are with BP Batam while the Batam City Government feels that it has the authority based on regional autonomy (Hadiyati, 2019). One of the dualisms that are most detrimental to the development of the Batam free trade zone area is the dualism of authority in investment administration services in Batam City which has a negative impact on investors. To avoid this conflict BP Batam and Pemko Batam have several times carried out Memorandum of Understanding and MOUs but there has been no realization of the implementation in the agreement agreement.

\begin{tabular}{|c|l|lr|}
\hline No & \multicolumn{1}{|c|}{ Agreement Form } & \multicolumn{2}{|c|}{ Deal Result } \\
\hline 1 & Keputusan Bersama & Formation & and \\
& Walikota Batam \& Ka. OB & Composition of the \\
& No 05 /SKB/HK/VI/2000 & Drafting Team for the \\
& & Draft Government \\
& & Regulation on Regulation \\
& & of the Batam City \\
& & Government's Working \\
\hline
\end{tabular}




\begin{tabular}{|c|l|l|}
\hline No & Agreement Form & \multicolumn{1}{|c|}{ Deal Result } \\
\hline \multirow{2}{*}{2} & $\begin{array}{l}\text { Relationship with the } \\
\text { Authority } \\
\text { Batam }\end{array}$ \\
\hline 2 & $\begin{array}{l}\text { Nota Kesepakatan antara } \\
\text { DPRD, Pemko Batam dan } \\
\text { Otorita Batam No. } \\
01 / 170 / N K / V I I I / 2006, \text { dan } \\
\text { Establish a harmonious } \\
\text { working relationship in } \\
\text { order to realize the vision } \\
\text { of the city of batam }\end{array}$ \\
\hline 3 & $\begin{array}{l}\text { Mou Walikota Batam \& Ka. } \\
\text { OB No.05/MOU/HK/V/2007, } \\
\text { dan N No.16/PERJ- } \\
\text { KA/V/2007 }\end{array}$ & $\begin{array}{l}\text { The duties and roles of } \\
\text { each party will be } \\
\text { comprehensively } \\
\text { regulated together with } \\
\text { the Batam City DPRD }\end{array}$ \\
\hline
\end{tabular}

Table 1. BP Institutional Agreements. Batam and Batam City

Government. Source: (Muzwardi, 2015)

To remove the dualism of authority involving BP Batam and Pemko Batam in the management and development of Batam Island, a proportional solution is needed. The protracted problem has an impact on the decline in the business and investment climate in Batam[1]. The Central Government as a party that has a big interest in Batam, is trying to end the problem. On September 17, 2019 the Central Government issued Government Regulation (PP) Number 62 of 2019 concerning Free Trade Areas and Free Ports of Batam, the PP finally ended the dualism of leadership in Batam City by appointing the Mayor of Batam as Head of BP Batam ex-officio. With the presence of the Mayor of Batam as ex-officio, the Head of BP Batam is expected to unite the interests of BP Batam and Pemko Batam. Based on terminology, ex-officio has a definition of a person's position in a certain institution based on his duties and authorities in other institutions. Defines ex-officio as another position that is inherent in a person because of a core position. The existence of the ex-officio itself is intended to facilitate coordination, cooperation, and harmonization of policies due to strong linkages with other functions so that an element of representation is needed (Suci et al., 2020).

\section{RESEARCH METHODS}

This study uses a qualitative approach. According to Shank, the qualitative approach is a systematic empirical approach (Manchester, 2011). The data analysis technique in this research is through data collection, data reduction and data presentation. Data collection techniques in this study used documentation studies and field studies. Documentation studies are carried out by collecting mass media data and government agency reports. Field studies in this study used two methods, namely: 1). through observation of the development of the Batam area; 2) conduct interviews with respondents who come from elements of Government and Corporations (Companies).

\section{RESULTS AND DISCUSSION}

The results and discussions studied are the results of research from the analysis of the ex-officio performance of the Head of BP Batam and the analysis of political relations in the ex-officio position of the Head of BP Batam.

\section{Ex-Officio Performance Analysis of the Head of BP Batam}

To analyze the ex-officio performance of the Head of BP Batam, the author uses a transformative leadership model. The transformative leadership model is used as a measuring tool in assessing the planning model and implementation of the ex-officio planning of the Head of BP Batam in the development of the Batam FTZ Area. The concept of transformational leadership is a leadership concept that devotes its attention to the problems at hand (Susilo, 2018). The concept of transformational leadership that can change the thinking of followers to adopt the organization's visions and missions so that the organization's visions and missions 
belong to all the work in it (Jiang et al., 2017). In assessing the transformational leadership performance of the ex-officio of the Head of BP Batam, the author analyzes the initial performance of the ex-officio of the Head of BP Batam in the areas of planning, harmonization of permits, and economic development in the Batam FTZ Area.

\section{Ex-officio Performance of the Head of BP Batam in Planning in the Batam FTZ Area}

Based on its function, the ex-officio of the Head of BP Batam is in charge of preparing the Batam FTZ area planning through the Strategic Plan (RENSTRA) of the Batam Free Trade Area and Free Port Concession Agency which is adjusted to the term of office of the Mayor of Batam, namely from 2020-2024. There are six strategies in the Strategic Plan for the development of the Batam Special Area, namely: 1) Increasing Private Investment; 2) Increasing the Availability of Supporting Infrastructure; 3) harmonize the Regulations; 4) Simplification of Regulations; 5) Increase Asset Utilization; and 6) Lowering Logistics Costs. The strategy is carried out by the ex officio Head of BP Batam through the establishment of the BP.Batam priority program. The Priority Programs include 1) Simplification of land permits regarding spatial planning; 2) Development of Batam as a Logistics Hub; 3) Development of Special Economic Zones; 4) Preparation of Water Needs; 5).Development of mass transportation.

The priority program in the BP Batam Strategic Plan is harmonized by the ex-officio of the Head of BP Batam with the Batam City Government development program. With the exofficio of the Head of BP Batam, Batam City can design its regional development in an integrated manner through a mutually supportive budget planning pattern. Based on BP.Batam's budget regulation, it refers to Government Regulation no. 6 of 2011 as a general basis for financial management and the Head of BP.Batam Regulation No.6 of 2012 concerning the management of the Batam Free Trade Zone and Free Port Concession Agency. On the other hand, the Batam City Government's budget management refers to Government Regulation no. 12 of 2019 as a general basis for financial management and Minister of Home Affairs Regulation No.77 of 2020 as a technical guideline for regional financial management.

BP Batam as the Business Entity, has a development and regional development budget that comes from commercially developed business units, while the business units are: Port Business Entity, Airport Business Entity, Hospital Business Entity, Facilities and Environment Business Entity. The income from these business units is included in the Non-Tax State Revenue (PNBP). Based on the realization of BP.Batam's revenue in 2020, the Business Entity that has the largest contribution among other Business Entities is the Port Business Entity with a contribution value of $53 \%$, while the Airport Business Entity has a contribution of $22 \%$.

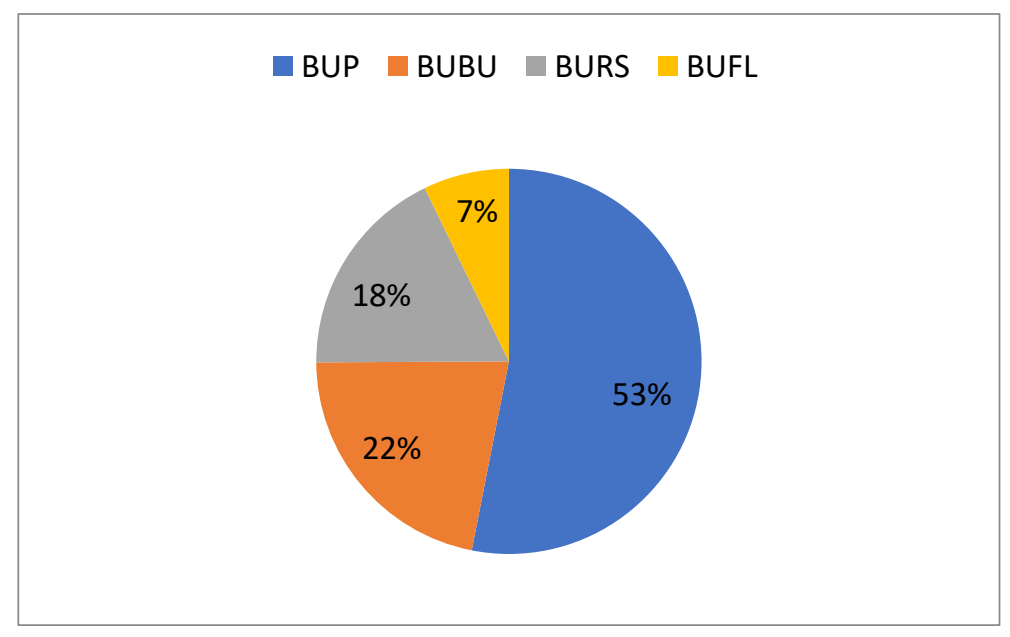

Picture 1. Percentage of Contribution of Business Entities to Revenues of BP.Batam Usaha Business Units (2020). Source : 
Rapat dengar pendapat antara Komisi VI DPR RI dengan Kepala BP Batam.

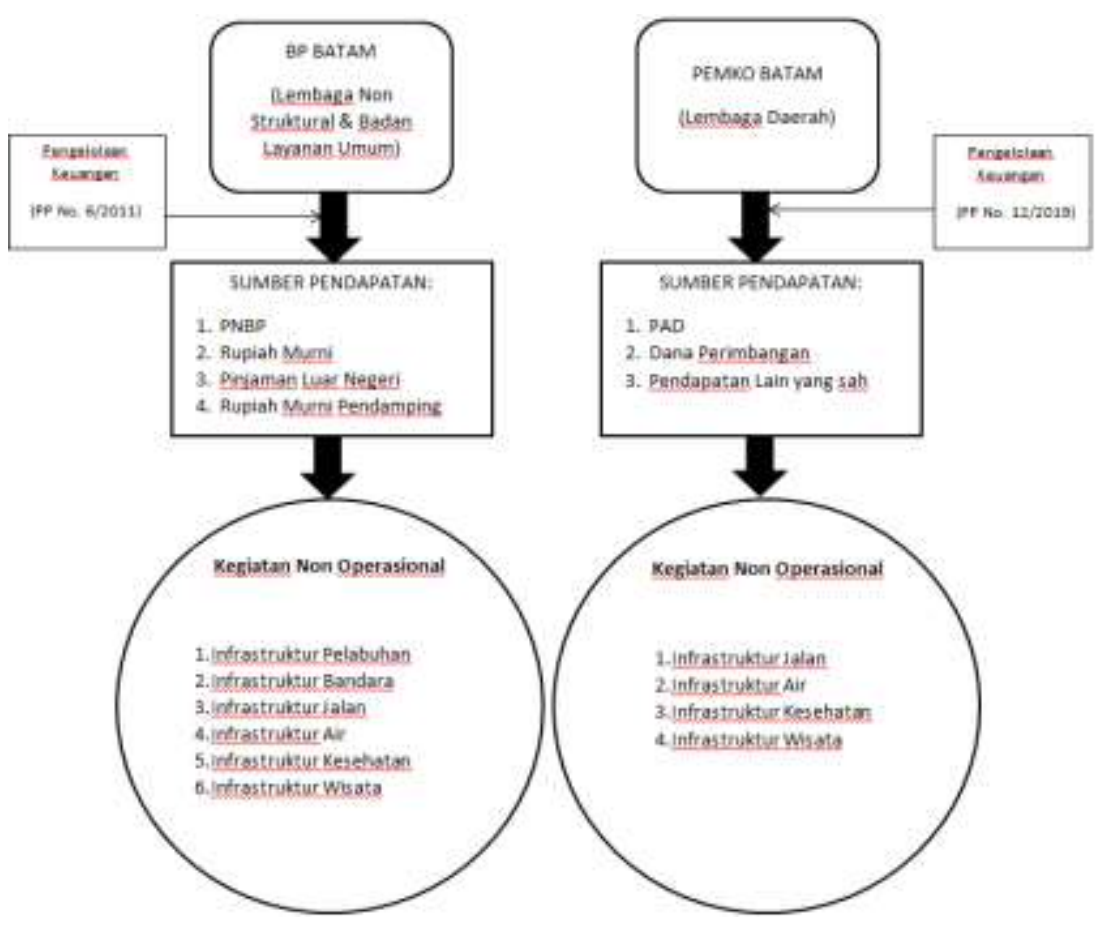

Picture 2. Comparison of BP Batam and Pemko Batam Financial Management Source: Author, 2021

The pattern of budget planning in infrastructure development in the early ex-officio period of the Head of BP Batam shows a well-organized planning, like BP. Batam is building supporting infrastructure to and from the port, while the Pemko is building the expansion and development of major intersections on access to and from industrial estates. In improving performance in the Batam FTZ area, the ex-officio of the Head of BP Batam builds communication with the central government and the national private sector as well as the foreign private sector to create synergies in regional development. To improve this performance, a measurable and targeted BP Batam Road Map is needed.

Based on the Road Map, BP Batam has more focus on the service sector, namely, industrial services, maintenance services, health services, education services and tourism services. The direction of Batam's development which was previously focused on optimizing the FTZ is now shifting to the establishment of a Special Economic Zone that has high selling value and is exclusive. The establishment of the Nongsa Digital Park Special Economic Zone which is a digital bridge between Indonesia and Singapore, as well as the development of the potential of Hang Nadim Airport as a Special Economic Zone for Maintenance Repair \& Overhaul (MRO) Batam Aero Technic, and the plan to develop the Batam Business Agency Hospital (RSBP) into health services.

\begin{tabular}{|l|l|}
\hline \multicolumn{1}{|c|}{ Road Map } & \multicolumn{1}{|c|}{ Initial implementation } \\
\hline $\begin{array}{l}\text { Manufacturing industries that } \\
\text { have high added value, such as } \\
\text { the smart phone and information } \\
\text { technology industries; }\end{array}$ & $\begin{array}{l}\text { Inauguration of Nongsa } \\
\text { Digital Park (NDP) into a } \\
\text { Special Economic Zone. }\end{array}$ \\
\hline
\end{tabular}




\begin{tabular}{|l|l|}
\hline \multicolumn{1}{|c|}{ Road Map } & \multicolumn{1}{|l|}{ Initial implementation } \\
\hline $\begin{array}{l}\text { Service industry, such as aircraft } \\
\text { and ship maintenance and } \\
\text { overhaul (MRO), shipyard and } \\
\text { shipbuilding, }\end{array}$ & $\begin{array}{l}\text { Signing of the addendum } \\
\text { text between BP Batam } \\
\text { and Lion Air related to the } \\
\text { MRO Batam Aero Technic } \\
\text { Land Lease }\end{array}$ \\
\hline $\begin{array}{l}\text { development of international } \\
\text { health and education services } \\
\text { and finance services }\end{array}$ & $\begin{array}{l}\text { Inauguration of 5 health } \\
\text { services, namely CT Scan } \\
128 \text { Slice, ICU PIE, } \\
\text { Polyclinic, Hospital } \\
\text { Management Information } \\
\text { System (SIMRS), and PCR } \\
\text { Laboratory. }\end{array}$ \\
\hline $\begin{array}{l}\text { Logistic hub, seperti } \\
\text { transshipment, e commerce, } \\
\text { warehouse dan infrastruktur link }\end{array}$ & $\begin{array}{l}\text { Peresmian Batam Logistics } \\
\text { Ecosystem (BLE) }\end{array}$ \\
\hline $\begin{array}{l}\text { Tourism that focuses on } \\
\text { creating tourist attractions and } \\
\text { developing creative industries }\end{array}$ & $\begin{array}{l}\text { Preparation of DED for } \\
\text { Sekupang Pond Park and } \\
\text { Deer Park }\end{array}$ \\
$\begin{array}{l}\text { Table 5. Initial Steps to Implement BP Batam Roadmap 2020- } \\
\text { 2024. Source: Author, 2021 }\end{array}$
\end{tabular}

\section{Ex-officio Performance of the Head of BP Batam in Harmonization of Permits in the Batam FTZ Area}

The establishment of the ex-officio of the Head of BP Batam aims to harmonize the licensing rules of the Batam City Government and BP Batam. The dualism and sectoral egos of the two institutions make the investment licensing system complicated, thus hampering investment in the Batam FTZ area. At the beginning of the ex-officio leadership of the Head of BP Batam, the innovation to harmonize licensing rules from the Batam City Government and BP Batam has not occurred. One of the reasons for the ex-officio of the Head of BP Batam is to speed up the processing of investor permits, in line with the expectations of the Coordinating Ministry for Economic Affairs as the institution that initiated the formation of the ex-officio of the Head of BP Batam (Sukarno, 2019)

The formation of transformational leadership at the ex-officio of the Head of BP Batam did not go according to the desired transformation. The planned transformational leadership has not fully integrated the service model. based on the results of interviews with respondents from corporate elements (private companies), the formation of the ex-officio of the Head of BP Batam only unites leadership styles but does not unify services (one room services). This service has not yet been harmonized, there are companies moving from Batam to other locations and the reluctance of prospective investors to invest in the Batam FTZ area. Exofficio Head of BP Batam in the early leadership period was more oriented towards physical infrastructure development rather than harmonization of licensing rules. The synergy between Pemko Batam and BP Batam which was built by the ex-officio of the Head of BP Batam is in the nature of infrastructure development and management (Nurdin, 2020).

\begin{tabular}{|l|l|}
\hline \multicolumn{1}{|c|}{ BP BATAM } & \multicolumn{2}{|l|}{ Batam City Government } \\
\hline Fatwa planologi & Advice planning \\
\hline titik reklame & Advertising license \\
\hline $\begin{array}{l}\text { Izin Penggunaan Ruang } \\
\text { Manfaat/Ruang Milik Jalan }\end{array}$ & $\begin{array}{l}\text { Road Benefit Space } \\
\text { Permit/ Street Owned } \\
\text { Space }\end{array}$ \\
\hline Izin Usaha & Business permit \\
\hline
\end{tabular}

Table 2. List of Permits in the Batam FTZ Area that have not been harmonized. Source: Author, 2021 


\section{Ex-officio Performance of the Head of BP Batam in Economic Development in the Batam FTZ Area}

The initial performance assessment of the ex-offico leadership of the Head of BP Batam was seen from the beginning of the end of 2019 until the end of 2020. At the beginning of the ex-offico leadership of the Head of BP Batam, To analyze the ex-offico performance of the Head of BP Batam in the development of the Batam FTZ area, the authors use assessment indicators, namely 1) Investment pictures; 2) export-import pictures; 3) GRDP; 4) Economic Growth; 5) inflation rate; 6) Various sectors that are indicators of Batam's success have experienced negative growth. Based on BKPM data for 2021, the realization of foreign investment growth in Batam City fell from $31 \%$ to $-77 \%$. The result of this negative growth is in line with the decline in the growth rate of investment projects from $61 \%$ in 2019 , to $-44 \%$ in 2020.

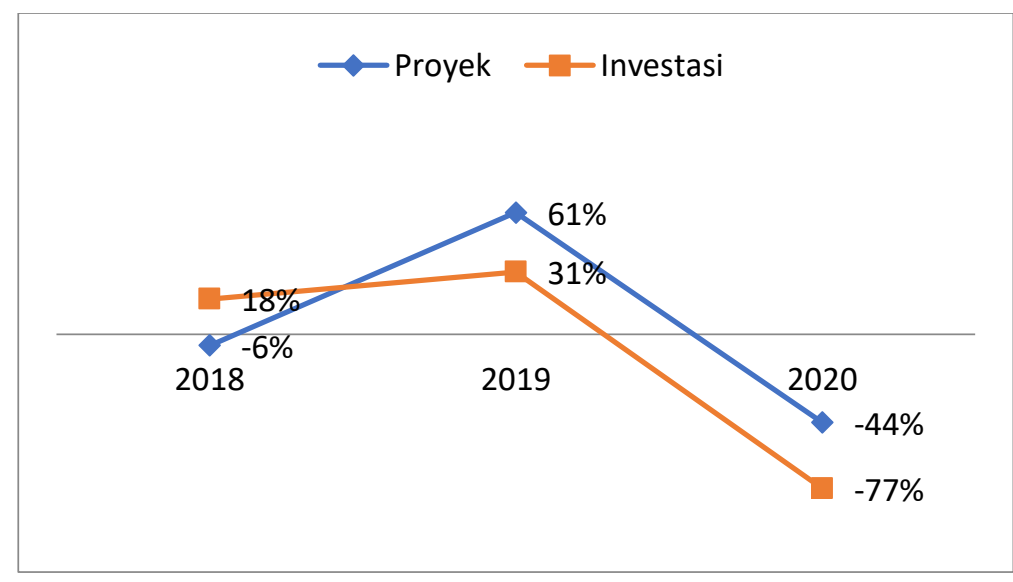

Picture 6. Growth in Investment Value and Number of Foreign Investment Projects (PMA). Source: Badan Koordinasi Penanaman Modal. 2019

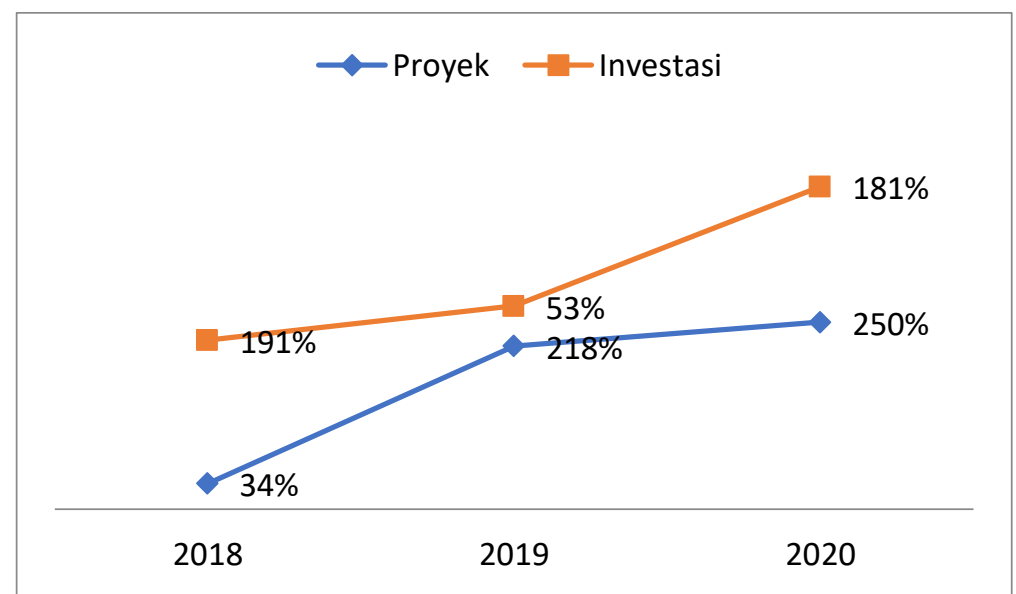

Picture 7. Growth in Investment Value and Number of Domestic Investment Projects (PMDN) Source: Source: Badan Koordinasi Penanaman Modal. 2019

One of the most important indicators of FTZ Batam is the export-import balance. Based on the analysis of BPS data, Batam's export balance experienced positive growth with $9 \%$ growth in 2020. On the other hand, imports decreased from $0 \%$ in 2019 to $-5 \%$ in 2020 . The positive value of the export-import balance shows the successful performance of the Batam area as a free trade zone. 


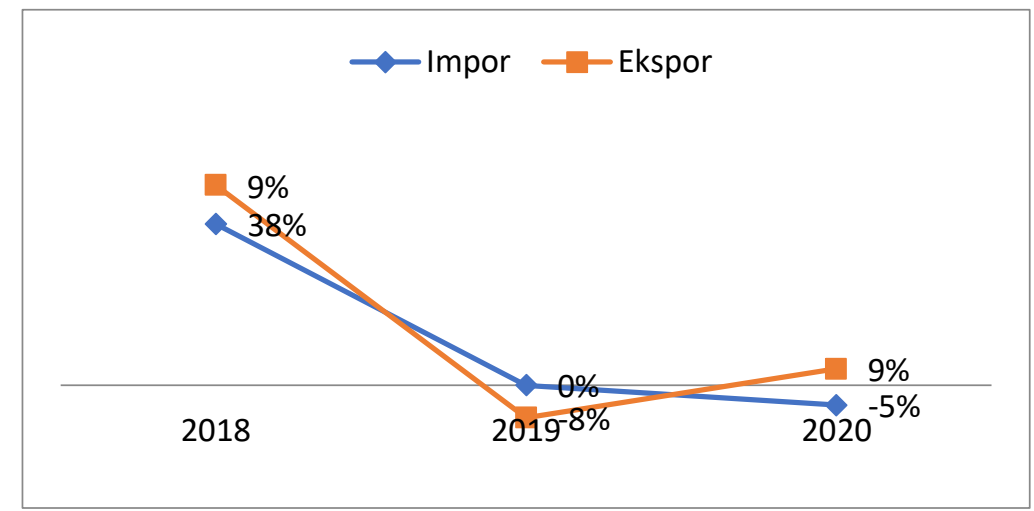

Picture 8. Percentage of Export Import Performance of Batam City Source : Badan Pusat Statistik Kota Batam (2020)

The COVID-19 pandemic has greatly impacted the GRDP of Batam City. in the period of 2020 Batam's GRDP growth rate fell to minus $2 \%$

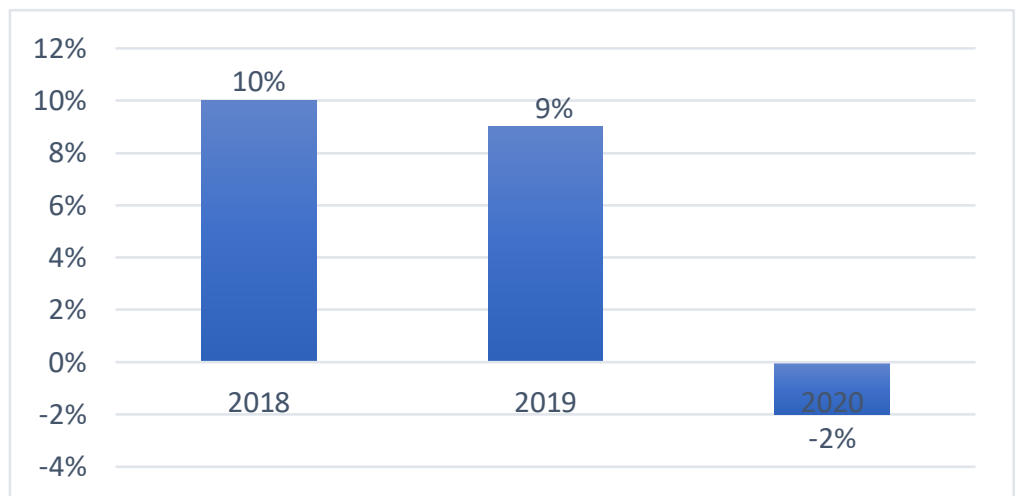

Picture 9. Percentage of GRDP Growth at the Current Prices of Batam City. Source : Badan Pusat Statistik Kota Batam (2021)

Although the growth rate in 2020 experienced a negative contraction of minus 2, Batam's contribution to the GRDP of the Riau Islands Province continued to increase. This shows that Batam's contribution remains high even in the midst of the COVID-19 pandemic.

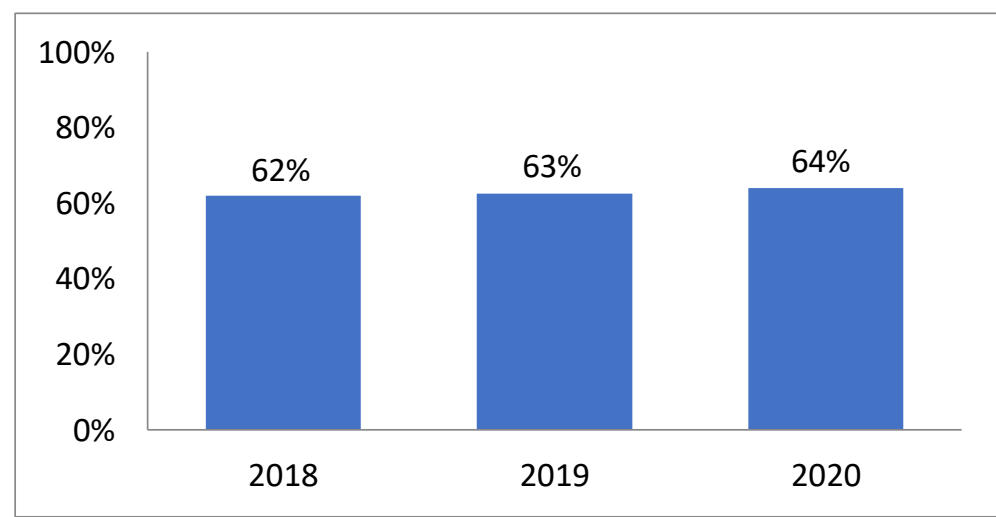

Picture 10. Percentage of Batam City's Contribution to Total GRDP of Riau Islands Province. Source: Badan Pusat Statistik Kota Batam. 2021 
Regarding the circulation of consumer goods that affect inflation, the ex.officio performance of the Head of BP.Batam is fairly positive. Based on BPS data, Batam's inflation rate growth in 2020 was only $1.12 \%$ lower than in 2019 , which was $1.97 \%$.

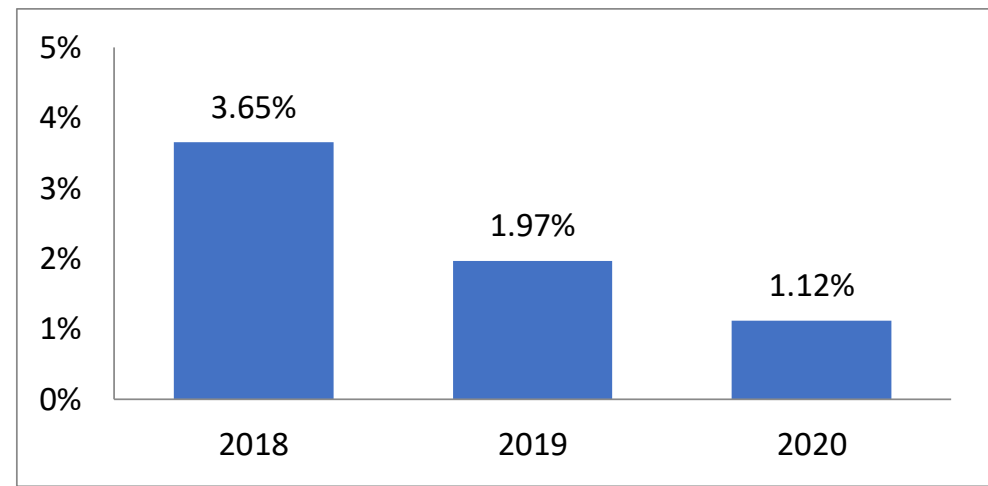

Picture 11. Inflation Growth in Batam City. Source: Badan Pusat Statistik Kota Batam. 2021

Economic growth is the most important indicator in the development of a region. The impact of Covid 19 that hit the global economy has an impact on the performance of national, provincial and city economic growth. based on BPS data, Batam's economic growth fell to minus $3 \%$, this picture is lower than the percentage of national economic growth.

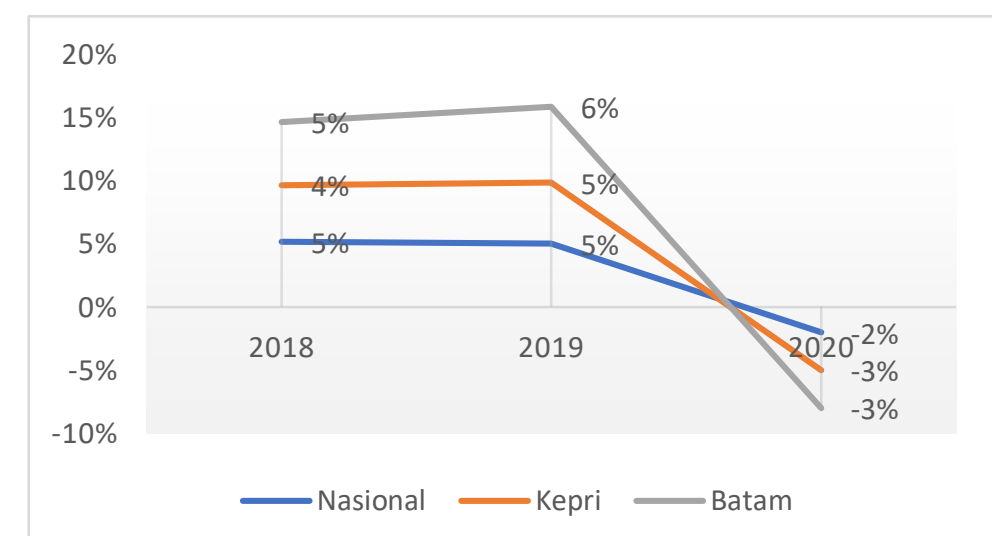

Picture 12. Batam Economic Growth. Source: Badan Pusat Statistik Kota Batam (2021).

The indicator of the success of the FTZ formulation is more about the multiple effects on the community, namely the increase in the level of participation of the TPAK workforce. In 2020 it was $68.22 \%$.

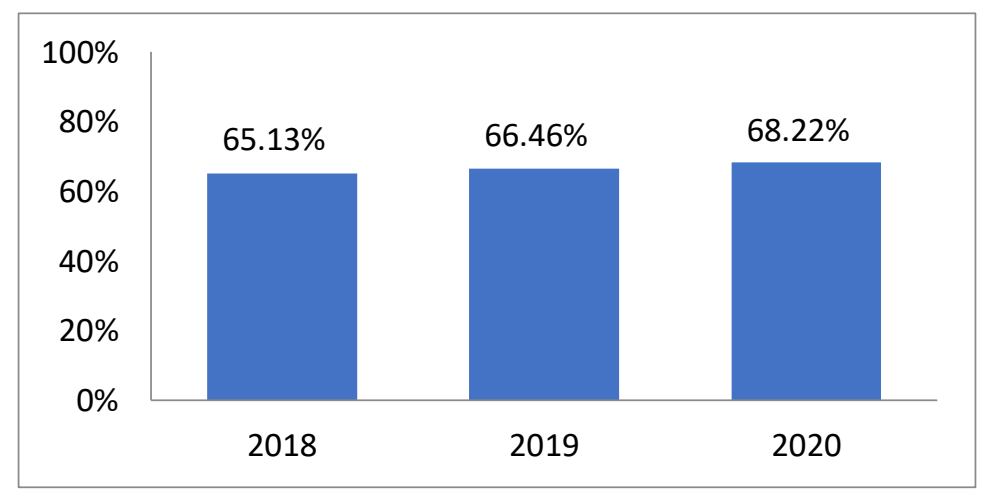

Picture 13. Batam City TPAK Labor Force Participation Rate.

Source: : Badan Pusat Statistik Kota Batam (2021). 


\section{Analysis of Political Relations in the Ex-Officio Position of the Head of BP Batam}

Seeing the background of the establishment of the ex-officio position of the Head of BP Batam, this position is an attempt by the central government to avoid political conflicts between the Batam City Government and the Batam Concession Board. with the ex-officio of the Head of BP Batam by the Mayor of Batam, there was a double position between the Regional Head and the Head of Non-Structural Institutions. This concurrent position has become commonplace in the Indonesian government system, for example, many non-structural institutions are occupied by state officials. Such as the Coordinating Minister for Economic Affairs who is also the Chairman of the Batam Regional Council

The Mayor of Batam is one of the state officials, this is based on Article 122 of the ASN Law and reinforced by Government Regulation of the Republic of Indonesia Number 63 of 2021 Article 3 paragraph 4 which explains the Regent/Mayor and Deputy Regent/Deputy Mayor including state officials. Based on the definition of PP No. 63 of 2021, State Officials are officials whose work environment is in state institutions which are state equipment and state institutions supporting the function of state equipment, tasked with carrying out functions for and on behalf of the state in accordance with the provisions of the legislation.

The position of Mayor of Batam is a political position, this is because this position is obtained through general elections. Regarding the definition of political office, according to Miftah Thoha, since the reform era, both bureaucratic career positions, state positions, and political positions have never been completely classified in the Indonesian state administration system. Therefore, the relationship between the three becomes unclear. Leaders of political parties who are elected by the people or appointed by those who are elected as state officials are not clear how far they are related to their political parties. Moreover, it is related to how far it is related to the use of state facilities, including the budget and employees who accompany the position (Charity, 2018). In particular, political officials themselves are appointed through political considerations (Dwimawanti, 2009).

\begin{tabular}{|l|l|}
\hline \multicolumn{1}{|c|}{$\begin{array}{c}\text { Task of the Head of BP } \\
\text { Batam }\end{array}$} & \multicolumn{1}{|c|}{ Batam Mayor task } \\
\hline $\begin{array}{l}\text { Leading the coordination of the } \\
\text { implementation of tasks, } \\
\text { coaching, and providing } \\
\text { administrative, financial and } \\
\text { human resource support to all } \\
\text { organizational units within the } \\
\text { Batam Concession Agency }\end{array}$ & $\begin{array}{l}\text { Lead the implementation of } \\
\text { Government Affairs }\end{array}$ \\
\hline $\begin{array}{l}\text { Leading the formulation and } \\
\text { implementation of provisions in } \\
\text { the field of strategic policies }\end{array}$ & $\begin{array}{l}\text { Maintain peace and order } \\
\text { in society }\end{array}$ \\
\hline $\begin{array}{l}\text { Leading the formulation and } \\
\text { implementation of provisions in } \\
\text { the field of area management } \\
\text { and investment }\end{array}$ & $\begin{array}{l}\text { prepare and submit a draft } \\
\text { regional regulation on the } \\
\text { RPJPD and a draft } \\
\text { regional regulation on the } \\
\text { RPJMD to the DPRD for } \\
\text { discussion with the DPRD, } \\
\text { as well as compile and } \\
\text { determine the RKPD }\end{array}$ \\
\hline $\begin{array}{l}\text { Leading the formulation and } \\
\text { implementation of provisions in } \\
\text { the field of business }\end{array}$ & $\begin{array}{l}\text { Drafting and submitting a } \\
\text { draft regional regulation on } \\
\text { APBD }\end{array}$ \\
\hline $\begin{array}{l}\text { Leading the management of } \\
\text { State property which is the } \\
\text { responsibility of the Batam } \\
\text { Concession Agency }\end{array}$ & $\begin{array}{l}\text { Represent the region } \\
\text { inside and outside the } \\
\text { court }\end{array}$ \\
\hline $\begin{array}{l}\text { Land management } \\
\text { and and }\end{array}$ & $\begin{array}{l}\text { Propose the appointment } \\
\text { of deputy regional heads }\end{array}$ \\
\hline
\end{tabular}




\begin{tabular}{|l|l|}
\hline \multicolumn{1}{|c|}{$\begin{array}{c}\text { Task of the Head of BP } \\
\text { Batam }\end{array}$} & \multicolumn{1}{|c|}{ Batam Mayor task } \\
\hline $\begin{array}{l}\text { Leading the task supervision BP } \\
\text { Batam }\end{array}$ & $\begin{array}{l}\text { Carry out other duties in } \\
\text { accordance with the } \\
\text { provisions of laws and } \\
\text { regulations }\end{array}$ \\
\hline
\end{tabular}

Table 3. Comparison of the Duties of the Head of BP Batam and the Duties of the Mayor Source: Processed from Batam Free Trade Zone and Free Port Council Regulation Number 1 of 2019 \& Law of the Republic of Indonesia Number 23 of 2014

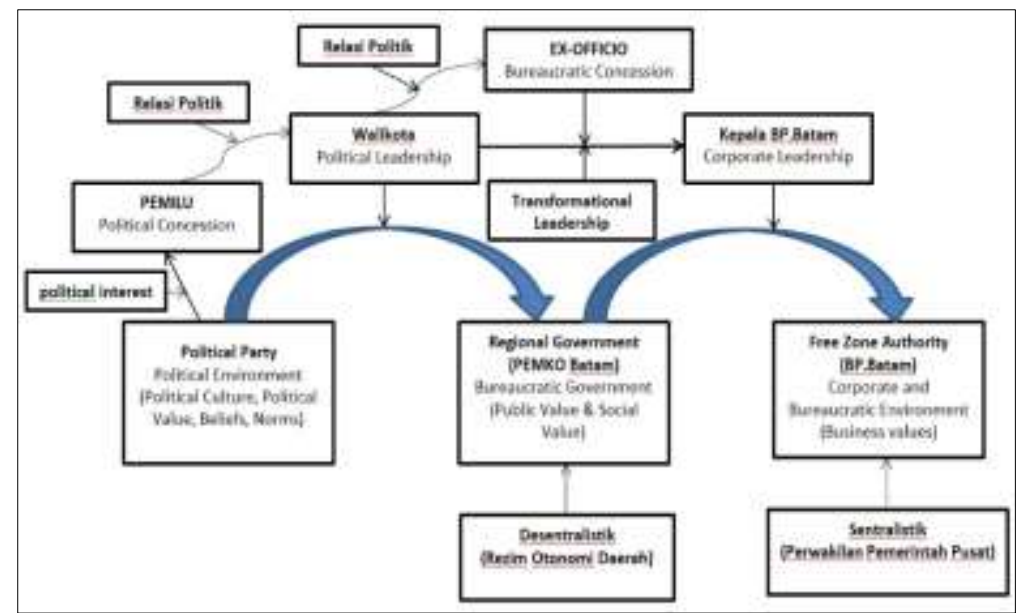

Picture 3. The Model for the Formation of an Ex-Officio Head of BP Batam and his political relations. Source: Author, 2021

Seen in Picture 3, the position of the Mayor of Batam has a direct relationship with the political party environment, because the Mayor of Batam is an official born from political concessions, while the ex-officio position of Head of BP Batam also has political relations because it is attached to the position of mayor, although the ex-officio position of Head of BP Batam BP Batam was born from a bureaucratic concession that aims as a middle way to unite the visions of the two government agencies. The presence of the Mayor of Batam as the exofficio of the Head of BP Batam gave birth to transformational leadership that could harmonize the bureaucratic environment at Pemko Batam with the bureaucratic environment at BP Batam.

The granting of the ex-officio position of the Head of BP Batam to the Mayor of Batam, has the consequence of having multiple positions. This consequence gives birth to leaders who must transform properly, because they lead two different institutions, namely the Regional Government Institution and the Non-Structural Institution in the form of a Public Service Agency, namely the Concession Agency. Isharyanto in his book entitled State Institutional Law defines Non-Structural Institutions as what in the literature are known as independent state institutions or supporting state institutions or state auxiliary state (Bolon, 2019; Yudiatmaja, 2020). Jimmy assidiqi, an expert in constitutional law, calls Non-Structural Institutions as special agencies. The objectives and benefits of establishing a Non-Structural Institution are: 1) Service efficiency; 2) Functional concentration/integration; 3) Independence from political intervention and preventing conflicts of interest; 4) The principle of dividing the functions of state power and government so that there is no overlap (Trisulog, 2015). In the process of forming the ex-officio of the Head of BP Batam, the most important part in this unification is the formation of transformational leadership that combines political culture and corporate culture. The unification of political culture and corporate culture will have a positive impact on the development of the Batam FTZ area if the ex-officio transformational leadership of the Head of BP Batam goes according to plan. 


\begin{tabular}{|l|l|}
\hline \multicolumn{1}{|c|}{ Advantage } & \multicolumn{1}{c|}{ Weakness } \\
\hline $\begin{array}{l}\text { Synchronization between } \\
\text { Batam City RPJMD and BP } \\
\text { Batam Strategic Plan }\end{array}$ & $\begin{array}{l}\text { The potential for the interests of } \\
\text { certain political parties }\end{array}$ \\
\hline Together Asset Utilization & $\begin{array}{l}\text { Potential for political pressure } \\
\text { from the legislature at the city } \\
\text { and provincial level }\end{array}$ \\
\hline $\begin{array}{l}\text { SOTK that supports each } \\
\text { other }\end{array}$ & - \\
\hline $\begin{array}{l}\text { Harmonization } \\
\text { services/licenses }\end{array}$ & - \\
\hline
\end{tabular}

Table 3. Advantages and Disadvantages of Ex-Officio Head of BP

Batam Source: Author, 2021

The ex-officio leadership of the Head of BP Batam cannot be separated from the potential for political interests. Utilization of the ex-officio position of the Head of BP Batam as political marketing, one of which was carried out when Muhammad Rudi as an incumbent in the Batam City Regional Head Election (Pilkada) in 2020, used the relationship of the exofficio position of the Head of BP Batam to increase his vote electability by including a plan BP Batam's work into the Vision and Mission of its political campaign. It can be seen from the analysis of the vision and mission of the main tasks and functions (tusi) of BP Batam which are part of Rudi's campaign program, development planning program and investment.

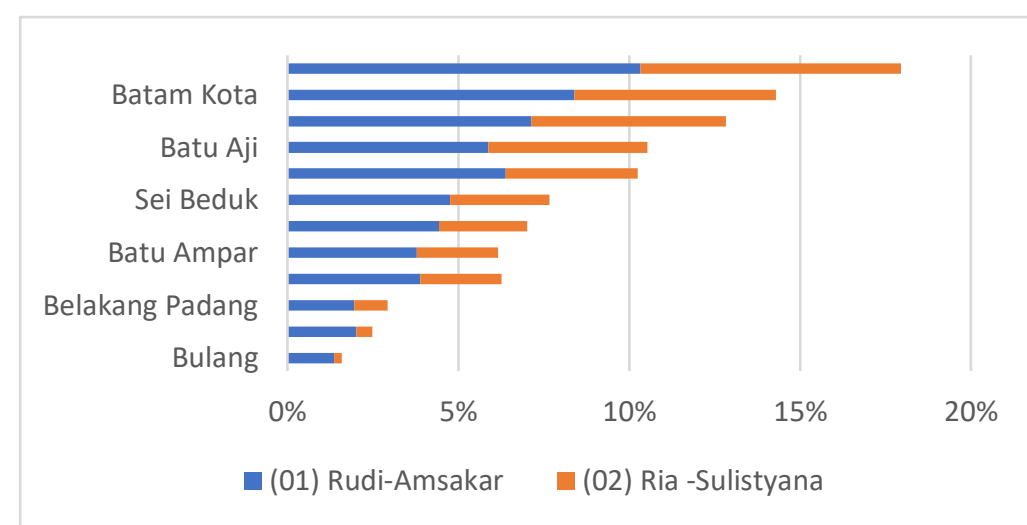

Picture 4. Percentage comparison of Rudi-Amsakar and RiaSulistyana Votes Suara (Pilkada Batam 2015). Source: Muzwardi et al (2021)

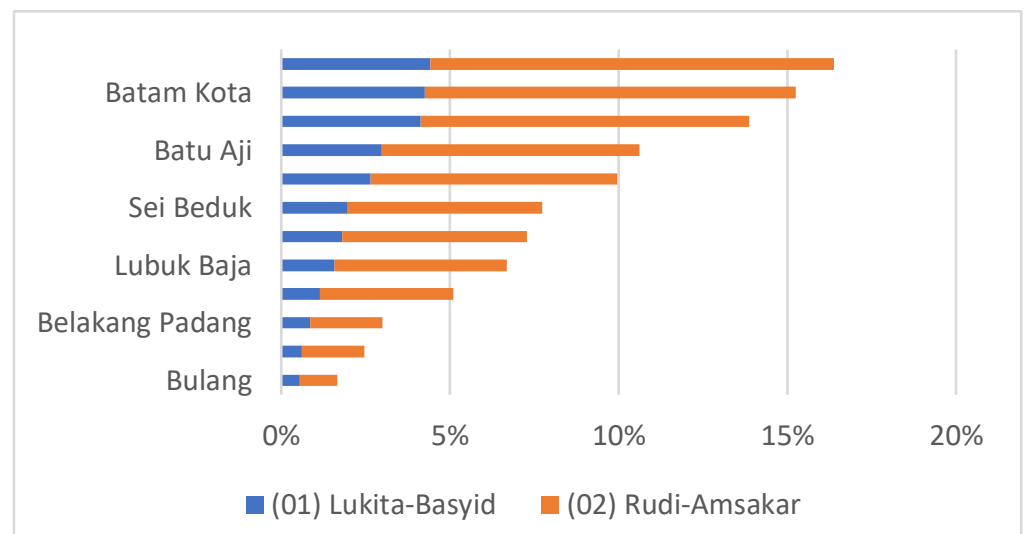

Picture 5. Percentage comparison of Rudi-Amsakar and Lukita-Basyid Votes (Pilkada Batam 2020). Source: (Muzwarid et al., 2021) 
The influence of the ex-officio position of the Head of BP Batam on the increase in the number of votes for Rudi, can be seen from the comparison of the number of votes at the time of nomination in the 2015 Batam Pilkada and the 2020 Batam Pilkada when he served as exofficio Head of BP Batam. The results of the percentage of votes from two This election showed an increase of $14 \%$ in Rudi's vote, from $60 \%$ in the 2015 Pilkada to $74 \%$ in the 2020 Pilkada.

\section{CONCLUSION}

Based on the analysis, the existence of the ex-officio of the Head of BP Batam has ended the dualism of leadership between BP Batam and Pemko Batam. But on the service side, the existence of the ex-officio of the Head of BP Batam has not had an impact on the harmonization of permits. On the other hand, political relations in the ex-officio position of the Head of BP Batam can be used as effective political marketing in the Regional Head Election. In the initial performance achievement, the ex-officio of the Head of BP showed a positive performance in his first year, this can be seen from the export-import balance, domestic investment, inflation and labor participation rates.

\section{ACKNOWLEDGMENT}

Acknowledgments to I Ketut Hadi Priatna as Head of the Legal, Trial, and Public Relations Bureau of the Coordinating Ministry for the Economy in providing his analysis regarding the ex-officio position of the Head of BP Batam.

\section{REFERENCE}

Alfiandri, A., \& Mahadiansar, M. (2020). Dampak Perencanaan Perubahan Free Trade Zone Menjadi Kawasan Ekonomi Khusus Di Kota Batam. KEMUDI: Jurnal IImu Pemerintahan, 4(2), 292-307. https://doi.org/10.31629/kemudi.v4i2.1945

Badan Koordinasi Penanaman Modal. (2019). Laporan Perkembangan Realisasi Investasi Berdasarkan Kabupaten-Kota Yahun 2019. BKPM.Jakarta.

Badan Koordinasi Penanaman Modal. (2019). Perkembangan Realisasi Investasi Berdasarkan Kabupaten-Kota Tahun 2019 s/d 2019. BKPM. Jakarta.

Badan Pusat Statistik Kota Batam. (2020). Statistik Ketenagakerjaan Kota batam 2020. BPS Kota Batam. Batam

Badan Pusat Statistik Kota Batam. (2021). Kota Batam dalam Angka 2021. BPS Kota Batam. Batam

Bolon, R. S. T. (2019). Analisis Pembubaran Lembaga Negara Nonstruktural Berdasarkan Peraturan Presiden Republik Indonesia Nomor 116 Tahun 2016 (Doctoral dissertation, IAIN BENGKULU). http://repository.iainbengkulu.ac.id/3873/

BP Batam, (2021). "Rapat dengar pendapat antara Komisi VI DPR RI dengan Kepala BP Batam. BP Batam. Jakarta.

Charity, M. L. (2018). Ironi Praktik Rangkap Jabatan Dalam Sistem Ketatanegaraan Indonesia. Jurnal Legislasi Indonesia, 13(1), 1-9. jurnal.peraturan.go.id/index.php/jil/article/view/81/pdf

Dalla, A. Y., \& Hutabarat, F. N. (2018). Tumpang Tindih Kewenangan Pengembangan Kawasan Ekonomi Khusus Batam. Matra Pembaruan: Jurnal Inovasi Kebijakan, 2(2), 139-148. https://doi.org/10.21787/mp.2.2.2018.139-148

Dwimawanti, I. H. (2009). Netralitas Birokrasi dan Kualitas Pelayanan Publik. Civil Service Journal, 3(1 Juni). https://jurnal.bkn.go.id/index.php/asn/article/view/144

E. Trisulo. E. (2015). Kajian Kelembagaan Sekretariat Komisi Informasi. Bidang Kelembagaan Komisi Informasi Pusat. Jakarta

Effendi, W. R., \& Sutarto, D. (2019). Dampak Konflik Kewenangan Antara Badan Pengusahaan Kota Batam Dan Pemerintah Kota Batam Terhadap Penerapan Good Governance Dalam Pelayanan Publik Di Kota Batam. Jurnal Dimensi, 8(1), 44-53. https://doi.org/10.33373/dms.v8i1.1847 
Hadiyati, N. (2019). Memahami Problematika Hak Pengelolaan Tanah Kota Batam Dalam Rangka Penetapan Batam Sebagai Kawasan Ekonomi Khusus. Jurnal Yurispruden, 2. http://dx.doi.org/10.33474/yur.v2i1.1660

Jiang, W., Zhao, X., \& Ni, J. (2017). The impact of transformational leadership on employee sustainable performance: The mediating role of organizational citizenship behavior. Sustainability, 9(9), 1567. https://doi.org/10.3390/su9091567

Manchester, R. A. (2011). Qualitative research in performing arts medicine. Medical problems of performing artists, 26(2), 63-64. https://doi.org/10.21091/mppa.2011.2010

Muzwardi, A. (2017). Free trade zone: menuju kawasan ekonomi khusus di Batam, Bintan, dan Karimun. Expert.

Muzwardi, A., \& Negara, S. D. (2021). Batam's 2020 Mayoral Election: Populism, Economic Recovery and Covid-19. https://think-asia.org/handle/11540/13168

Muzwardi. A. (2015). Analisa hubungan antar organisasi (networking governance) dalam pengembangan investasi di Kawasan Perdagangan dan Pelabuhan Bebas Batam. Master Tesis, Universitas Muhammadiyah Yogyakarta

Nurdin, A. (2020). Gebrakan BP Batam di Tangan Ex Officio. Bisnis Liputan 6. diakses dari https://www.liputan6.com/bisnis/read/4160172/gebrakan-bp-batam-di-tangan-ex-officio

Peraturan Kepala Badan Pengusahaan Batam Nomor 18 Tahun 2012. Pengelolaan Keuangan Badan Pengusahaan Kawasan Perdagangan Bebas dan Pelabuhan Bebas Batam.1 Januari 2013. Badan Pengusahaan Batam. Batam

Peraturan Menteri Dalam Negeri Nomor 77 Tahun 2020.Pedoman Teknis Pengelolaan Keuangan Daerah. 30 Desember 2020. Kemendagri. Jakarta

Peraturan Pemerintah Nomor 12 Tahun 2019. Pengelolaan Keuangan Daerah. 06 Maret 2019. Lembaran Negara Republik Indonesia Tahun 2019 Nomor 42. Jakarta

Peraturan Pemerintah Republik Indonesia Nomor 6 Tahun 2011. Pengelolaan Keuangan Pada Badan Pengusahaan Kawasan Perdagangan Bebas Dan Pelabuhan Bebas Batam. 4 Februari 2011.Lembaran Negara Republik Indonesia Tahun 2011 Nomor 17. Jakarta

Peraturan Pemerintah Republik Indonesia Nomor 62 Tahun 2019 tentang Perubahan Kedua Atas Peraturan Pemerintah Nomor 46 Tahun 2007 Tentang Kawasan Perdagangan Bebas Dan Pelabuhan Bebas Batam.11 September 2019. Lembaran Negara Republik Indonesia Tahun 2019 Nomor 165. Jakarta

Rezkisari. I. (2021). Rangkap Jabatan Wali Kota Batam Maksimal Hingga 2024. Republika Online. diakses dari https://www.republika.co.id/berita/qpiyq8328/

Suci, A., Maryanti, S., Van FC, L. L., \& Yandra, A. (2020). Dilema Ex-Officio Terkait Pencegahan Korupsi Dan Penjaminan Mutu Di Perguruan Tinggi Swasta. Jurnal Penjaminan Mutu, 6(1), 1-14. http://dx.doi.org/10.25078/jpm.v6i1.1169

Sukarno, P. P. (2019). Peleburan BP Batam Jadikan Proses Pengurusan Izin Usaha Lebih Cepat. Bisnis.Com. diakses dari. https://ekonomi.bisnis.com/read/20190107/9/876260/peleburan-bp-batam-jadikanproses-pengurusan-izin-usaha-lebih-cepat

Susilo, D. (2018). Transformational leadership: a style of motivating employees. MEC-J (Management and Economics Journal), 2(2), 109-116. https://doi.org/10.18860/mecj.v0i1.5222

Undang-Undang Republik Indonesia Nomor 21 Tahun 2011. Otoritas Jasa Keuangan.22 November 2011. Lembaran Negara Republik Indonesia Tahun 2011 Nomor 111. Jakarta

Zaenuddin, M., Kumorotomo, W., Saleh, S., \& Hadna, A. H. (2017). Dualisme Kelembagaan antara Pemerintah Kota dan Badan Pengusahaan Batam Serta Dampaknya terhadap Kinerja Perekonomian di Kota Batam. Journal of Applied Business Administration, 1(2), 219-231. https://doi.org/10.30871/jaba.v1i2.613

Yudiatmaja, W. E. (2021). Public service motivation and service quality of local government employees: A moderated mediation analysis. Policy \& Governance Review, 5(1), 33-49. https://doi.org/10.30589/pgr.v5i1.357 